\title{
Tu Weiming. Wprowadzenie do filozofii współczesnego konfucjanisty
}

\author{
Alfred Skorupka \\ (Politechnika Śląska, Wydział Inżynierii Materiałowej i Metalurgii)
}

\begin{abstract}
Streszczenie
Tu Weiming (ur. w 1940 r.) jest jednym z najbardziej znanych żyjących konfucjanistów. Artykuł zawiera omówienie jego poglądów na temat współczesnego oblicza konfucjanizmu, wyłożonych w eseju Confucius: The Embodiment of Faith in Humanity. Autor komentuje tę propozycję z punktu widzenia chrześcijaństwa i tradycji filozoficznej Zachodu.
\end{abstract}

Słowa kluczowe: Tu Weiming, konfucjanizm, konfucjusz, nowy konfucjanizm

\section{Summary}

\section{Tu Weiming: Introduction to the Philosophy of a Contemporary Confucianist}

$\mathrm{Tu}$ Weiming (born 1940) is one of the most famous contemporary confucianists. In this article his views concerning Confucianism in contemporary times presented in essay Confucius: The Embodiment of Faith in Humanity (Konfucjusz: uosobienie wiary w ludzkość) are discussed. The author presents his comment from the point of view of Christianity and Western philosophical tradition.

Keywords: Tu Weiming, Confucianism, Confucius, New Confucianism 